\title{
Phytoprotection
}

\section{Impact of pirimiphos-methyl and cold temperatures on arthropod populations in stored wheat}

\author{
N.D.G. White, D.S. Jayas et R.N. Sinha
}

Volume 75, numéro 2, 1994

URI : https://id.erudit.org/iderudit/706054ar

DOI : https://doi.org/10.7202/706054ar

Aller au sommaire du numéro

Éditeur(s)

Société de protection des plantes du Québec (SPPQ)l

\section{ISSN}

0031-9511 (imprimé)

1710-1603 (numérique)

Découvrir la revue

\section{Citer cet article}

White, N., Jayas, D. \& Sinha, R. (1994). Impact of pirimiphos-methyl and cold temperatures on arthropod populations in stored wheat. Phytoprotection, 75(2), 79-90. https://doi.org/10.7202/706054ar
Résumé de l'article

Appliqué à une concentration moyenne de $6,4 \mathrm{mg}$ m.a. $\mathrm{kg}^{-1}$ à $5 \mathrm{t}$ de ble (Triticum aestivum) dans un grenier du sud du Manitoba, l'insecticide pyrimiphos-méthyl est resté actif pendant plus de 24 mo. La plupart des insectes et des acariens qui vivaient dans le grain traité n'ont pu survivre, à l'exception d'un psoque, Liposcelis sp., ainsi que les acariens Tarsonemus granarius et Aeroglyphus robustus, dont les populations ont été considérablement réduites par rapport à celles qui vivaient dans du blé non traité. À $1 \mathrm{~m}$ de profondeur, la concentration en résidus de l'insecticide a diminué de $52 \%$ en $12 \mathrm{mo}$, passant de $8,1 \mathrm{mg} \mathrm{kg}^{-1}$ à $4,0 \mathrm{mg} \mathrm{kg}^{-1}$ puis est restée stable jusqu'à la fin de la période de $24 \mathrm{mo}$. La teneur en humidité du grain à cette profondeur était constamment supérieure (plus de 14\%) à celle mesurée en surface du blé, où les résidus sont demeurés à une concentration voisine de $4,5 \mathrm{mg} \mathrm{kg}^{-1}$ pendant les $24 \mathrm{mo}$. La température du blé fluctuait entre des maximums estivaux voisins de $23^{\circ} \mathrm{C}$ et des minimums hivernaux de près de $-40^{\circ} \mathrm{C}$ à la surface du blé. Après 24 mo d'entreposage, du blé traité a été contaminé avec des adultes du Tribolium castaneum; le taux de mortalité observé a été d'environ $80 \%$. Des populations de $T$. castaneum ou de Rhyzopertha dominica introduites dans $5 \mathrm{t}$ de blé non traité ne se sont pas établies; de petites populations de Cryptolestes ferrugineus se sont établies, mais elles ont été éliminées par le froid. Les populations de Liposcelis sp. et des acariens A robustus, T. granarius, Blattisocius keegani et de Cheyletus eruditus étaient les plus élevées à la fin de l'été et en automne. La germination des grains et la microflore n'ont pas été directement affectées par le pyrimiphos-méthyl. La lente décomposition de cet insecticide dans le grain empêcherait des communautés d'arthropodes de se développer autant que dans un écosystème constitué de blé entreposé et non traité sur une période de 24 mo.
Ce document est protégé par la loi sur le droit d'auteur. L’utilisation des services d'Érudit (y compris la reproduction) est assujettie à sa politique d'utilisation que vous pouvez consulter en ligne.

https://apropos.erudit.org/fr/usagers/politique-dutilisation/ 


\title{
Impact of pirimiphos-methyl and cold temperatures on arthropod populations in stored wheat
}

\author{
Noël D.G. White ${ }^{1}$, Digvir S. Jayas ${ }^{2}$, and Ranendra N. Sinha ${ }^{1}$
}

Received 1994-02-02; accepted 1994-10-24

The insecticide pirimiphos-methyl applied at a mean concentration of 6.4 $\mathrm{mg}$ a.i. $\mathrm{kg}^{-1}$ to $5 \mathrm{t}$ of wheat (Triticum aestivum) in a farm granary in southern Manitoba remained active over 24 mo. Most insects and mites in the treated grain could not survive except a psocid, Liposcelis sp., and the mites Tarsonemus granarius and Aeroglyphus robustus, and their populations were sharply reduced relative to those in a bulk of untreated wheat. Insecticide residues at a 1-m depth decreased ca. $52 \%$ in 12 mo from $8.1 \mathrm{mg}$ $\mathrm{kg}^{-1}$ to $4.0 \mathrm{mg} \mathrm{kg}^{-1}$, then remained constant until 24 mo. Grain moisture content $(\mathrm{MC})$ at this depth was consistently higher (over $14 \% \mathrm{MC}$ ) than at the top of the wheat bulk where residues remained near $4.5 \mathrm{mg} \mathrm{kg}^{-1}$ over 24 mo. Grain temperatures fluctuated from summer maxima near $23^{\circ} \mathrm{C}$ to winter minima near $-40^{\circ} \mathrm{C}$ at the bulk surface. Bioassay of treated wheat with adult Tribolium castaneum after 24 mo of storage resulted in about $80 \%$ mortality. Populations of T. castaneum or Rhyzopertha dominica introduced into $5 \mathrm{t}$ of untreated wheat did not become established; small populations of Cryptolestes ferrugineus were established but were eliminated by winter cold. Populations of Liposcelis sp. and the mites A. robustus, T. granarius, Blattisocius keegani and Cheyletus eruditus were highest in late summer and autumn. Seed germination and microflora were not directly affected by pirimiphos-methyl. The slow rate of degradation of this insecticide in grain would prevent communities of arthropods from developing to the same extent as in an untreated stored-wheat ecosystem over 24 mo.

White, N.D.G., D.S. Jayas, and R.N. Sinha. 1994. Effet du pyrimiphosméthyl et du froid sur les populations d'arthropodes dans le blé entreposé. PHYTOPROTECTION 75: 79-90.

Appliqué à une concentration moyenne de $6,4 \mathrm{mg} \mathrm{m} . \mathrm{a} . \mathrm{kg}^{-1}$ à $5 \mathrm{t}$ de blé (Triticum aestivum) dans un grenier du sud du Manitoba, l'insecticide pyrimiphos-méthyl est resté actif pendant plus de 24 mo. La plupart des insectes et des acariens qui vivaient dans le grain traité n'ont pu survivre, à l'exception d'un psoque, Liposcelis sp., ainsi que les acariens Tarsonemus granarius et Aeroglyphus robustus, dont les populations ont été considérablement réduites par rapport à celles qui vivaient dans du blé non traité. À $1 \mathrm{~m}$ de profondeur, la concentration en résidus de l'insecticide a diminué de $52 \%$ en 12 mo, passant de $8,1 \mathrm{mg} \mathrm{kg}^{-1}$ à $4,0 \mathrm{mg} \mathrm{kg}^{-1}$, puis est restée stable jusqu'à la fin de la période de 24 mo. La teneur en humidité du grain à cette profondeur était constamment supérieure (plus de 14\%)

1. Agriculture and Agri-Food Canada, Research Centre, 195 Dafoe Road, Winnipeg, Manitoba, Canada R3T 2M9. Contribution $n^{\circ} 1573$

2. Department of Agricultural Engineering, University of Manitoba, Winnipeg, Manitoba, Canada R3T 5V6 
à celle mesurée en surface du blé, où les résidus sont demeurés à une concentration voisine de $4,5 \mathrm{mg} \mathrm{kg}^{-1}$ pendant les $24 \mathrm{mo}$. La température du blé fluctuait entre des maximums estivaux voisins de $23^{\circ} \mathrm{C}$ et des minimums hivernaux de près de $-40^{\circ} \mathrm{C}$ à la surface du blé. Après $24 \mathrm{mo} \mathrm{d}^{\prime} \mathrm{en}$ treposage, du blé traité a été contaminé avec des adultes du Tribolium castaneum; le taux de mortalité observé a été d'environ $80 \%$. Des populations de T. castaneum ou de Rhyzopertha dominica introduites dans $5 \mathrm{t}$ de blé non traité ne se sont pas établies; de petites populations de Cryptolestes ferrugineus se sont établies, mais elles ont été éliminées par le froid. Les populations de Liposcelis sp. et des acariens A. robustus, $T$. granarius, Blattisocius keegani et de Cheyletus eruditus étaient les plus élevées à la fin de l'été et en automne. La germination des grains et la microflore n'ont pas été directement affectées par le pyrimiphos-méthyl. La lente décomposition de cet insecticide dans le grain empêcherait des communautés d'arthropodes de se développer autant que dans un écosystème constitué de blé entreposé et non traité sur une période de 24 mo.

\section{INTRODUCTION}

Stored-grain ecosystems, such as those found in undisturbed farm granaries, can consist of communities of insects, mites, and fungi that interact in complex ways with one another, the grain and the physical environment (Dunkel 1992) The aim of stored-grain management is to minimize biological activity which causes seed deterioration. One of the tools that can be used to protect grain are contact insecticides which have long-term activity on the grain (Snelson 1987).

Protectant insecticides have a significant, but often selective, impact on species in stored-grain ecosystems (White and Sinha 1990; White et al. 1986). The rate of insecticide degradation and the potential for the return of pest insects and mites under specific climatic conditions must be understood for sound decision-making.

Pirimiphos-methyl (2-diethylamine-6methylpyrimidin-4-yl dimethyl phosphorothionate) is a grain protectant used widely around the world (Snelson 1987) and is registered for use on corn (Zea mays L.) in the United States (White and Leesch 1995). Although pirimiphosmethyl is not registered for use on grain in Canada, its efficacy must be defined under Canadian storage conditions for it to be considered as an alternative to malathion (S-[1,2-di(ethoxycarbonyl) ethyl]dimethyl phosphorothiolothio- nate). Malathion is currently the main grain protectant registered for cereals used for human consumption in Canada, but insect pest resistance to this insecticide is becoming more widespread (Schaafsma 1990; White and Loschiavo 1985). Synergized pyrethrum is also registered for grain application but is expensive and has short residual activity; diatomaceous earth is registered for use on seed grain (White and Leesch 1995).

The aim of this study was to determine the impact of pirimiphos-methyl on insects and mites in a stored-wheat (Triticum aestivum L.) ecosystem over 2 yr in western Canada.

\section{MATERIALS AND METHODS}

\section{Experimental design}

A wooden granary at Glenlea, Manitoba, $\left(49^{\circ} 38^{\prime} \mathrm{N} 97^{\circ} 08^{\prime} \mathrm{W}\right)$ was divided into two bins with a $150-\mathrm{cm}$ high plywood barrier. The granary was $3.6 \mathrm{~m}$ long and $3.0 \mathrm{~m}$ wide and each bin held $5 \mathrm{t}$ of Canada western hard red spring wheat. One bin was filled with untreated wheat and then temporarily covered with a plastic sheet to prevent surface contamination from dust carrying insecticide. Pirimiphos-methyl was then applied to wheat entering the auger using a drip mechanism (Quinlan et al. 1979) that gave a mean dosage of $6.4 \mathrm{mg}$ a.i. $\mathrm{kg}^{-1}$. The other bin was filled with this insecticide-treated wheat. 
The grain top-surface in each bin was divided with two transects and marked with numbered stakes. Copperconstantan thermocouples were placed at the grain top, at a 1-m depth, and at the floor level (1.4 $\mathrm{m}$ deep) in the four corners and in the centre of each bin.

Grain samples were taken at 10 fixed locations in each bin near the thermocouples (five each at the top and at the $1-\mathrm{m}$ depth). Samples of $200 \mathrm{~mL}$ of wheat were taken with a brass torpedo probe from each location; samples were placed in plastic bags, sealed and returned to the laboratory for analyses. Duplicate samples were taken from the treated wheat for insecticide analysis. Samples were taken monthly from 24 July 1990 until August 1992, except during January and February 1991 and 1992 because temperatures were then too low for biological activity. Temperatures were recorded at the thermocouple locations with a potentiometer on each sampling day.

Insects were reared in the laboratory at $30^{\circ} \mathrm{C}, 70 \% \mathrm{RH}$ on whole wheat and wheat germ (19:1, wt:wt) for all species except Tribolium castaneum (Herbst) [Coleoptera: Tenebrionidae], which were reared on wheat flour and brewer's yeast (19:1, wt:wt). Insects were added to the grain surface in each bin on 4 September 1990 (5000 adults each of $T$. castaneum and Cryptolestes ferrugineus (Stephens) [Coleoptera: Cucujidae] per bin); on 4 June 1991 (2500 adults each of $T$. castaneum, $C$. ferrugineus, Rhyzopertha dominica [F.] [Coleoptera: Bostrichidae] per bin); and on 25 September 1991 ( 5000 adults each of $T$. castaneum and $C$. ferrugineus per bin).

\section{Sample analysis}

A $50-\mathrm{mL}$ subsample of wheat was taken monthly from each sample to determine seed moisture content, and at $1 \mathrm{wk}$ and 24 mo for seed-borne microflora and seed germination. Seed moisture content of each sample was determined by drying $5-\mathrm{g}$ samples at $130^{\circ} \mathrm{C}$ for $19 \mathrm{~h}$ (ASAE 1990). Seed-borne microflora were examined from all samples at the beginning and end of the study by placing three replicates of 25 seeds sample $^{-1}$ on filter paper saturated with
$7.5 \%$ aqueous $\mathrm{NaCl}$ solution in Petri dishes (Mills et al. 1978). The dishes were placed in plastic bags at $22 \pm 1^{\circ} \mathrm{C}$ for $7 \mathrm{~d}$, after which microfloral growth was identified and counted under a binocular microscope. Seed germination was determined using filter paper saturated with distilled water for another three replicates of 25 seeds sample ${ }^{-1}$ (Wallace and Sinha 1962).

Arthropods were removed from the wheat by placing the remaining $150 \mathrm{~mL}$ of samples in Berlese funnels for $24 \mathrm{~h}$ and collecting mites and insects in $70 \%$ ethanol in bottles under the funnels (Sinha 1964). The arthropods were identified and counted under a binocular microscope.

\section{Bioassay of insecticide-treated grain} Insecticide-treated samples of wheat were assayed at every sampling date with adult red flour beetles, $T$. castaneum, to monitor residual toxicity. The insects had no insecticide resistance and were taken from laboratory cultures maintained at $30 \pm 1{ }^{\circ} \mathrm{C}$ and $70 \pm 5 \% \mathrm{RH}$ on wheat flour and brewer's yeast (19:1, wt:wt). Two plastic vials each containing $10 \mathrm{~g}$ of wheat and 25 adult $T$. castaneum were used for each sample. The insects were kept on the wheat for 24 $h$ at $30 \pm 1{ }^{\circ} \mathrm{C}$ and $70 \pm 5 \% \mathrm{RH}$, then removed and the numbers of incapacitated insects observed. All insects were then placed in corresponding plastic vials containing untreated, ground whole wheat to permit recovery of exposed insects and held at $30 \pm 1{ }^{\circ} \mathrm{C}$ and $70 \pm 5 \% \mathrm{RH}$ for 1 wk when mortality was recorded. Controls consisted of six vials of wheat taken from the control bin at each sampling date tested in a manner identical to that of the treated wheat.

\section{Chemical assay of insecticide residues}

The levels of insecticide residues were determined in triplicate for all samples of treated wheat on five sampling dates. Samples for insecticide analysis were taken 24 July 1990 ( 1 wk), 4 March 1991 (7 mo), 8 July 1991 (12 mo), 30 March 1992 (19 mo), and 4 August 1992 (24 mo). For each sample, $10 \mathrm{~g}$ of wheat 
were ground for $1 \mathrm{~min}$ in an electric coffee grinder (Model KSM 2, Braun Canada Ltd., Mississauga, Ont.). Ground wheat $(4 \mathrm{~g})$ was placed in a steel tube with two steel balls and $30 \mathrm{~mL}$ acetone. The tube was sealed and placed in a Burrell wrist-action shaker (Burrell Corporation, Pittsburgh, PA) for $1 \mathrm{~h}$. The acetone-lipid extract was filtered through a Buchner funnel using a vacuum. The acetone was then separated from the lipids in a rotary evaporator under vacuum using a water bath at 44$48^{\circ} \mathrm{C}$. The lipid extract was transferred to the top of a gel-permeation chromatography column using four ethyl acetate rinses of $1 \mathrm{~mL}$ on a thistle funnel. The columns (35-cm high, $1.9-\mathrm{cm}$ diam) were each packed with $21 \mathrm{~g}$ of Biobeads S-X2 (Bio-Rad Laboratories, Richmond, CA) swollen in ethyl acetate. Eluant was collected in a graduated cylinder by maintaining a constant head of ethyl acetate at the top of the column. The first $85 \mathrm{~mL}$ of eluted ethyl acetate were discarded. The next $40 \mathrm{~mL}$ of ethyl acetate, which contained the insecticide but not wheat lipids, were collected and concentrated using a vacuum rotary evaporator at $55-59^{\circ} \mathrm{C}$.

The extract was then redissolved in $10 \mathrm{~mL}$ of hexane containing an internal standard of the organophosphorus insecticide pirimiphos-ethyl (2-diethylamino-6-methyl-4-pyrimidinyl diethyl phosphorothioate). Three $\mu \mathrm{L}$ of solution were injected into a Perkin-Elmer Sigma 3B gas chromatograph that was equipped with a nitrogen-phosphorus detector $\left(\mathrm{N}_{2}\right.$ carrier gas flow of $25 \mathrm{~mL} \mathrm{~min}^{-1}$ ), a 90 $\mathrm{cm} \times 6.4-\mathrm{mm}$ internal diameter glass column packed with $3 \%$ (wt:wt) OV-17 on chromosorb W-HP 100/120 mesh, and a Sigma 15 data integrator. The temperature of the injector was $225^{\circ} \mathrm{C}$, the detector $250^{\circ} \mathrm{C}$, and the oven was at $200^{\circ} \mathrm{C}$ (isothermic). The efficiency of recovery of pirimiphos-methyl when $28.9 \mu \mathrm{g}$ were added to $4 \mathrm{~g}$ of wheat was $96 \pm 1 \%(n=10)$ with the methodology outlined.

The statistical analyses used to compare potentially similar variables from this study were ANOVA, and Duncan's new multiple range test.

\section{RESULTS}

\section{Grain temperature and moisture content}

Grain temperature and grain moisture content were identical in both bins. Maximum mean grain temperatures were $22^{\circ} \mathrm{C}$ at the top and $1-\mathrm{m}$ depth in August $1990 ; 20^{\circ} \mathrm{C}$ at the top in June and $23^{\circ} \mathrm{C}$ at $1-\mathrm{m}$ depth in August 1991 ; and $18^{\circ} \mathrm{C}$ at the top in July and $16^{\circ} \mathrm{C}$ at 1-m depth in August 1992 (Fig. 1). The coldest temperatures monitored were $-10^{\circ} \mathrm{C}$ at the top and $1-\mathrm{m}$ depth in March 1991; and $-16^{\circ} \mathrm{C}$ at the top and $-4^{\circ} \mathrm{C}$ at $1-\mathrm{m}$ depth in December 1991. During January and February, the monthly mean ambient air temperatures (from Environment Canada, Atmospheric Environment Service - Glenlea Station) were $-20^{\circ} \mathrm{C}$ (mean max. $-13^{\circ} \mathrm{C}$, mean min. $-26^{\circ} \mathrm{C}$ ) and $-10.5^{\circ} \mathrm{C}$ (mean max. $-5^{\circ} \mathrm{C}$, mean min. $-16^{\circ} \mathrm{C}$ ) respectively in 1991 , and $-13^{\circ} \mathrm{C}$ (mean max. $-7^{\circ} \mathrm{C}$, mean min. $-19^{\circ} \mathrm{C}$ ) and $-11^{\circ} \mathrm{C}$ (mean max. $-6^{\circ} \mathrm{C}$, mean min. $-17^{\circ} \mathrm{C}$ ), respectively in 1992. The lowest air temperature was $40^{\circ} \mathrm{C}$ in January 1991. The top of the grain bulk was warmer in the spring and summer and cooler in the winter than at $1-m$ deep because of the insulating properties of grain (Alagusundaram et al. 1990).

Moisture content (MC) of the wheat at $1-\mathrm{m}$ depth remained constant at about $14.5 \%$ over 24 mo but fluctuated at the top of the grain bulks in response to changing ambient relative humidity (Fig. 2). It fell to $12-13 \% M C$ during the summers and rose to a high of $13.8 \% \mathrm{MC}$ during winters. The moisture content was significantly lower $(P<0.05)$ at the top of the grain bulk than at the $1-\mathrm{m}$ depth.

\section{Insecticide degradation}

The initial mean ( $X \pm S E$ ) levels of pirimiphos-methyl were $4.7 \pm 0.8 \mathrm{mg}$ $\mathrm{kg}^{-1}$ at the top and $8.1 \pm 1.5 \mathrm{mg} \mathrm{kg}^{-1}$ at the $1-\mathrm{m}$ depth with an overall mean based on all samples of $6.4 \pm 1.0 \mathrm{mg}$ $\mathrm{kg}^{-1}$ (Fig. 3). The observed mean insecticide level was close to our calculated level of $6 \mathrm{mg} \mathrm{kg}^{-1}$ even though the addition of insecticide to a varying flow of grain entering an auger often results 


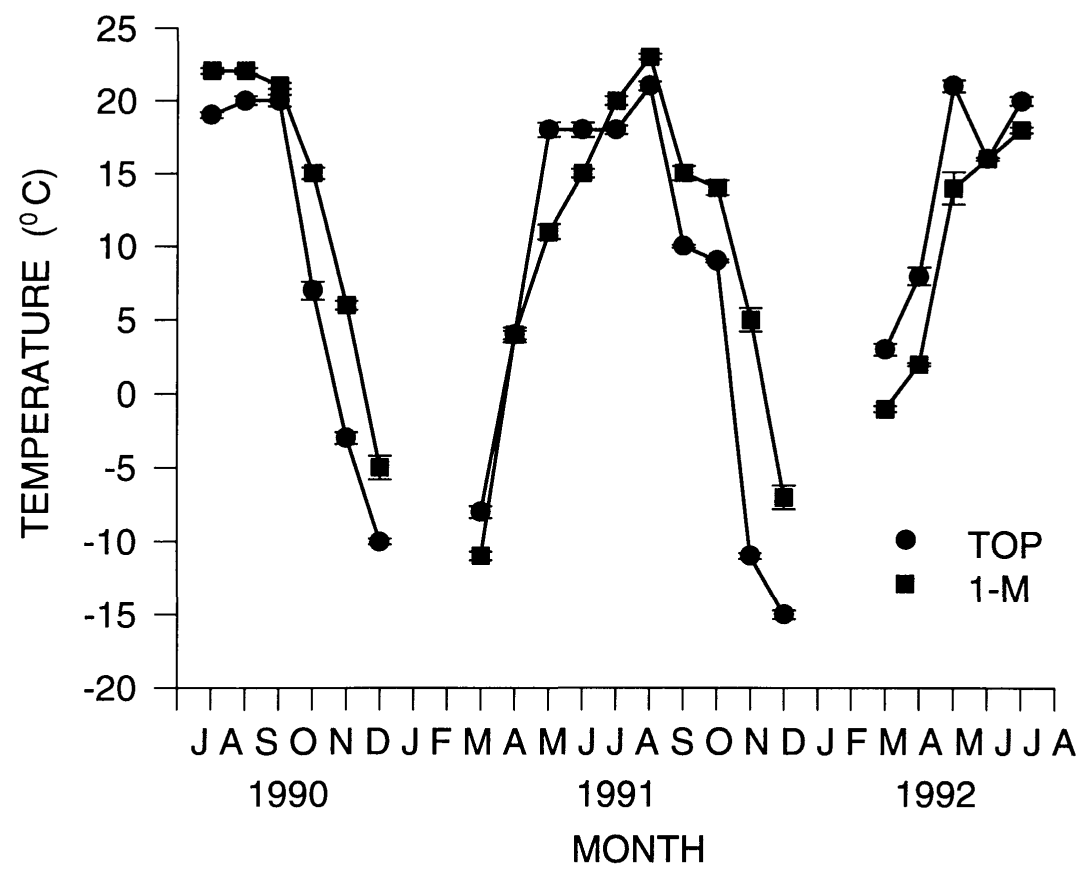

Figure 1. Mean temperatures at the top of two grain bulks and at 1-m depth over 24 mo of storage.

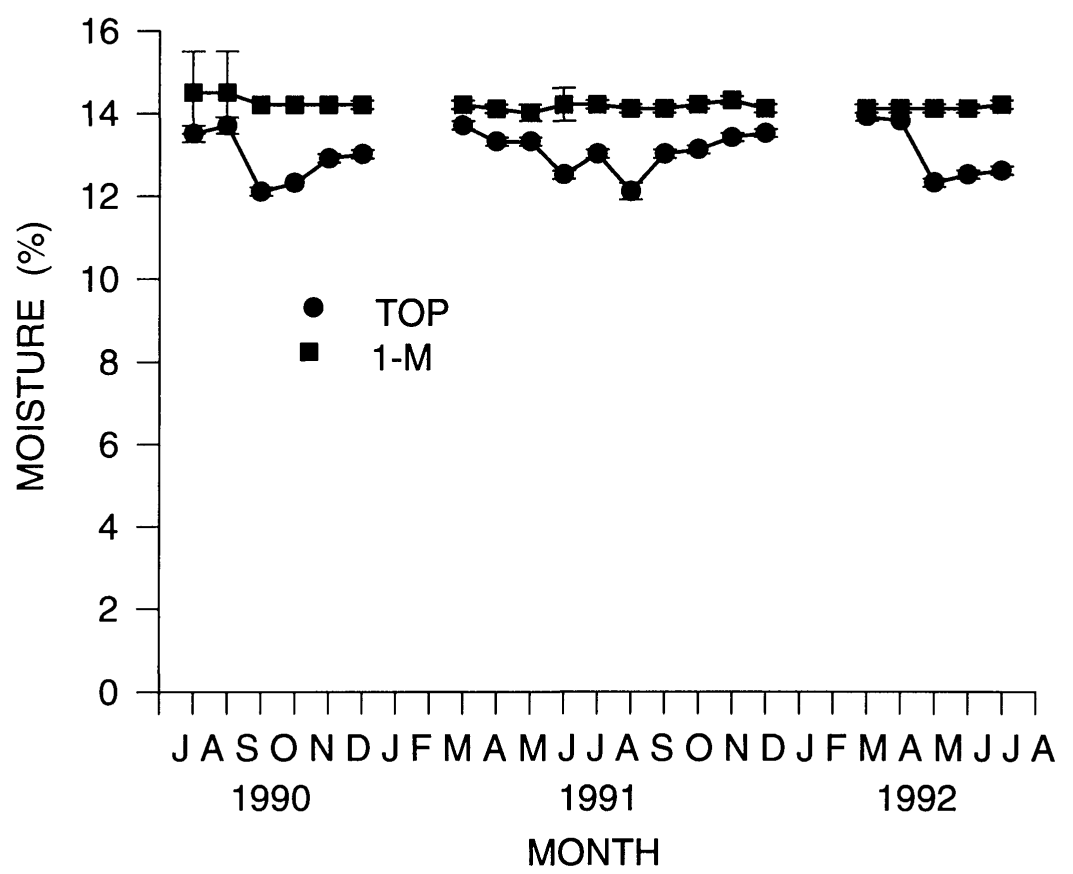

Figure 2. Mean moisture content of grain at the top of two grain bulks and at 1-m depth over 24 mo of storage. 


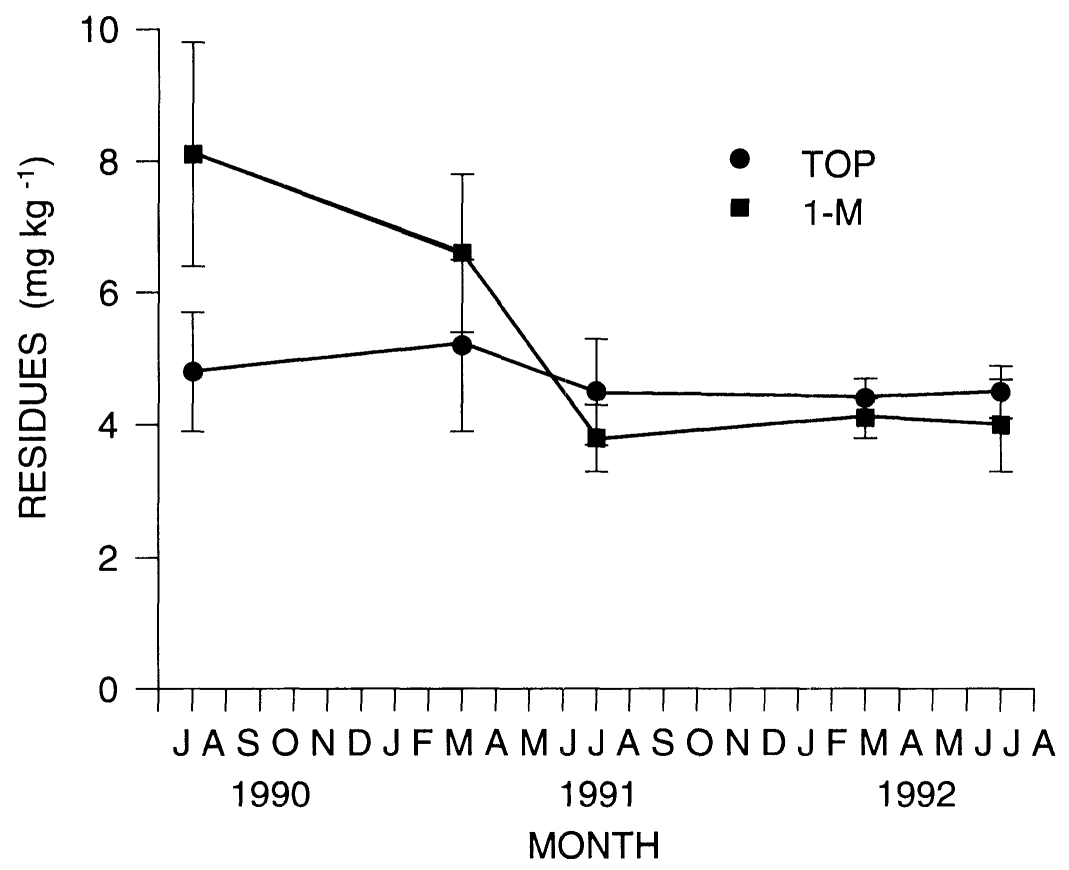

Figure 3. Mean pirimiphos-methyl residues from the grain bulk surface and 1-m depth on wheat stored for 24 mo.

in uneven coverage (White et al. 1983) (Fig. 3). At the time of initial application there was a significant difference but after 8 mo of storage there was no significant difference in residue levels at the top or $1-\mathrm{m}$ depth in the grain bulk $(P>0.05)$.

Insecticide levels at the top of the grain bulk remained relatively unchanged over $2 \mathrm{yr}$ where the grain moisture content was lowest and fluctuated from $12 \%$ to $13.8 \%$, but remained below $13 \%$ MC during the warmer months (Figs. 2, 3). At the 1-m depth, mean insecticide levels fell by $52 \%$ in 12 mo and then remained relatively unchanged to 24 mo after treatment. Grain moisture levels were consistently above $14 \%$ during 24 mo at this depth.

\section{Bioassay}

Mortality of Tribolium castaneum adults exposed for $24 \mathrm{~h}$ to treated grain samples (1-m depth level) remained near $100 \%$ until 24 mo when it fell to a mean of $84 \%$ (Fig. 4), even though insecticide levels remained at $4 \mathrm{mg} \mathrm{kg}^{-1}$. Mean mortality on surface samples declined from $95 \%$ at $7 \mathrm{mo}$ to $80 \%$ by $24 \mathrm{mo}$ (Fig. 4) when insecticide levels were $4.5 \mathrm{mg}$ $\mathrm{kg}^{-1}$. Since insecticide levels did not change between 12 and 24 mo, but bioassay mortality declined, it is likely that the chemical was gradually moving into the seed so insects would be exposed to less insecticide on contact with the seed surface. Lipophilic insecticides such as pirimiphos-methyl are known to accumulate in the germ and bran of cereal seeds in storage (Mensah et al. 1979). Control mortality never exceeded $5 \%$.

\section{Insects}

For 2-3 mo following introduction of insects in the untreated bin, only a few Cryptolestes ferrugineus were detected in grain samples (Fig. 5A). Cool grain inhibited insect reproduction, even in summer; populations of $C$. ferrugineus, T. castaneum and Rhyzopertha dominica were unable to survive the cold winter temperatures (Fields 1992). Only the psocid, Liposcelis sp. [Psocoptera: Liposcelidae], maintained a low popu- 
lation (mean maximum of 8.5 adults $150 \mathrm{~mL}^{-1}$ wheat at $1-\mathrm{m}$ depth in September 1991) over the 24 mo (Fig. 5B).

All introduced insects died within 1 mo in the bin treated with pirimiphos-methyl. However, Liposcelis sp. had means of about 0.2 adults $150 \mathrm{~mL}^{-1}$ wheat at both the top and 1-m depth levels during several of the warm months of each year (Fig. 5C).

\section{Mites}

In the untreated grain, Tarsonemus granarius Lindquist [Acari: Tarsonemidae] was present in low numbers in 1991 and 1992. The predominant arthropod in the untreated grain was Aeroglyphus robustus (Banks) [Acari: Glycyphagidae] which is common in Canadian grain and can feed on grain and fungal diets, and can tolerate temperatures of $-39^{\circ} \mathrm{C}$ in the hypopal stage (Sinha 1966). In 1990, A. robustus was more common at 1-m depth than at the grain surface (Fig. 6A). In 1991, it was equally abundant at the top and at the 1-m depth, reaching densities of around 200 mites $150 \mathrm{~mL}^{-1}$ wheat late in the year. In 1992, A. robustus was more abundant at the top of the grain bulk than at the 1-m depth, reaching a peak density of 450 mites $150 \mathrm{~mL}^{-1}$ wheat (Fig. 6A). The predatory mites Cheyletus eruditus (Schrank) [Acari: Cheyletidae], and notably Blattisocius keegani Fox [Acari: Ascidae], were present in low numbers in 1991 corresponding to peak $A$. robustus numbers. In August 1992, C. eruditus numbers increased sharply (28 C. eruditus $150 \mathrm{~mL}^{-1}$ wheat) (Fig. 6B) in response to the large populations of $A$. robustus at the top of the grain bulk (Fig. 6A). Few mites survived in the treated grain although a few $A$. robustus were detected after 12 mo of storage. Tarsonemus granarius was largely unaffected by the insecticide (Fig. 6C), and it was detected after 5 mo of storage and reached a maximum density of 11 mites $150 \mathrm{~mL}^{-1}$ wheat at 16 mo of storage at 1-m depth in the grain.

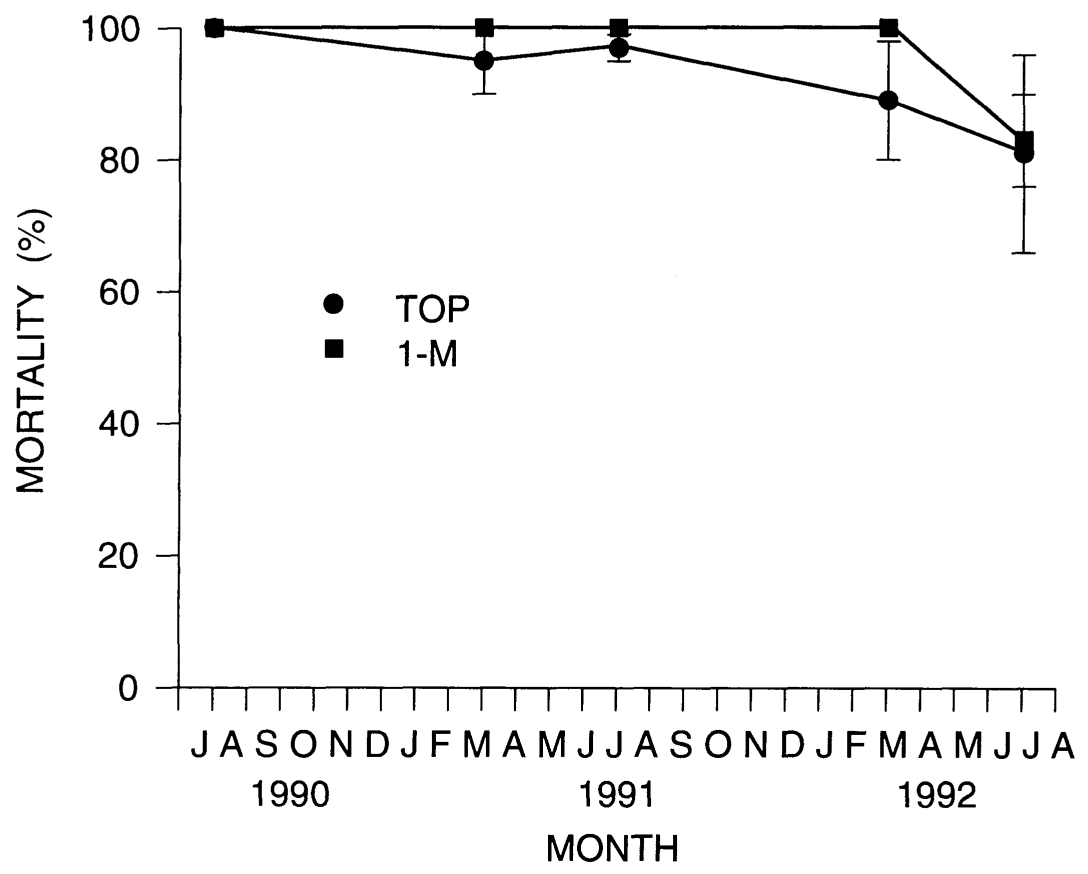

Figure 4. Mean mortality of Tribolium castaneum adults used for laboratory bioassay of wheat from the grain bulk surface and 1-m depth treated with pirimiphos-methyl and stored for 24 mo. Control mortality was always $<5 \%$. 

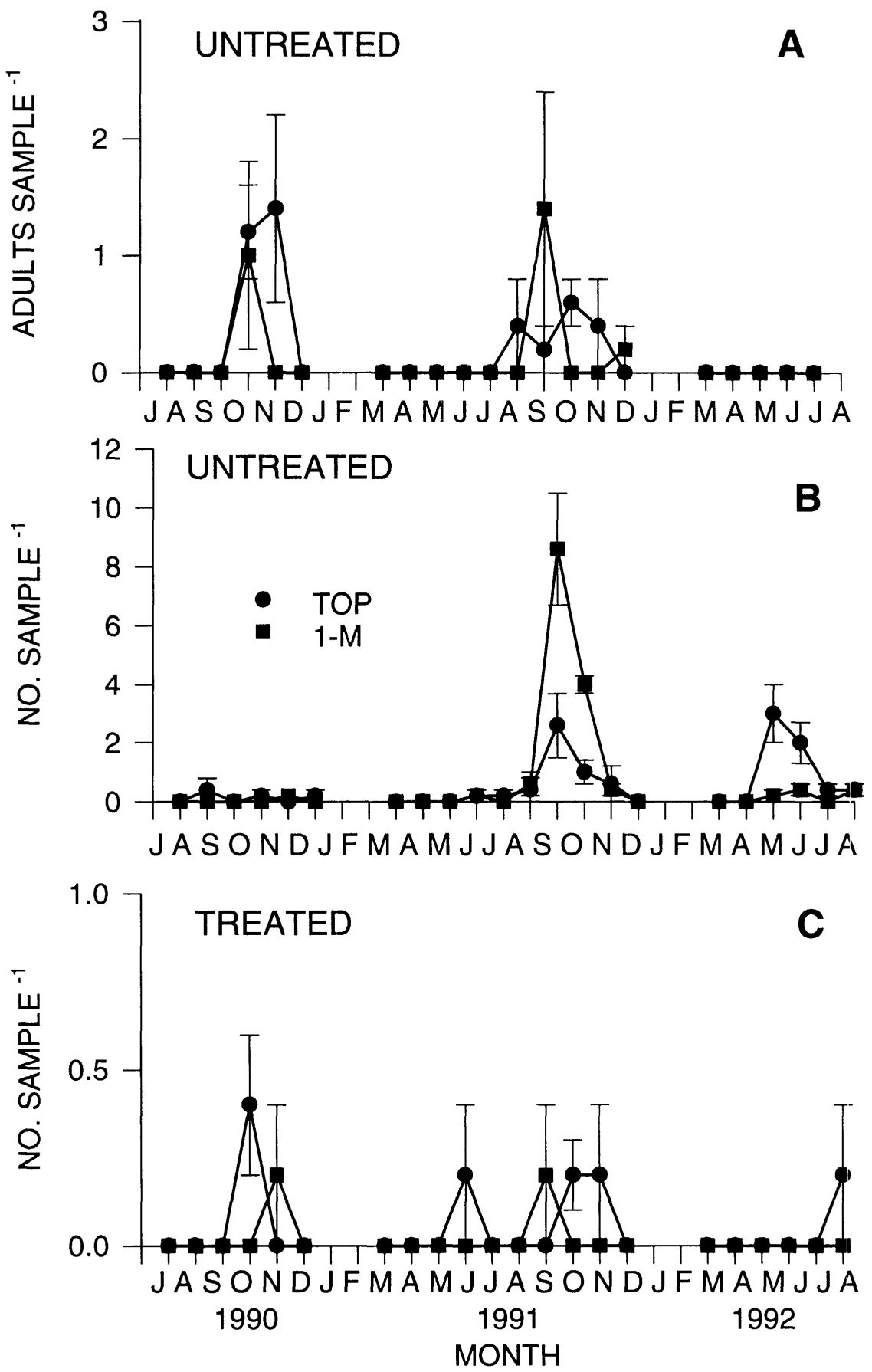

Figure 5. Mean number $(X \pm S E ; n=5)$ of insects $150 \mathrm{~mL}^{-1}$ of wheat taken monthly, except January and February, over a 24-mo period from the top or 1-m depth of bulks of untreated grain or grain treated with pirimiphos-methyl. A) Adult Cryptolestes ferrugineus in untreated wheat; B) Liposcelis sp. in untreated wheat; C) Liposcelis sp. in treated wheat. 

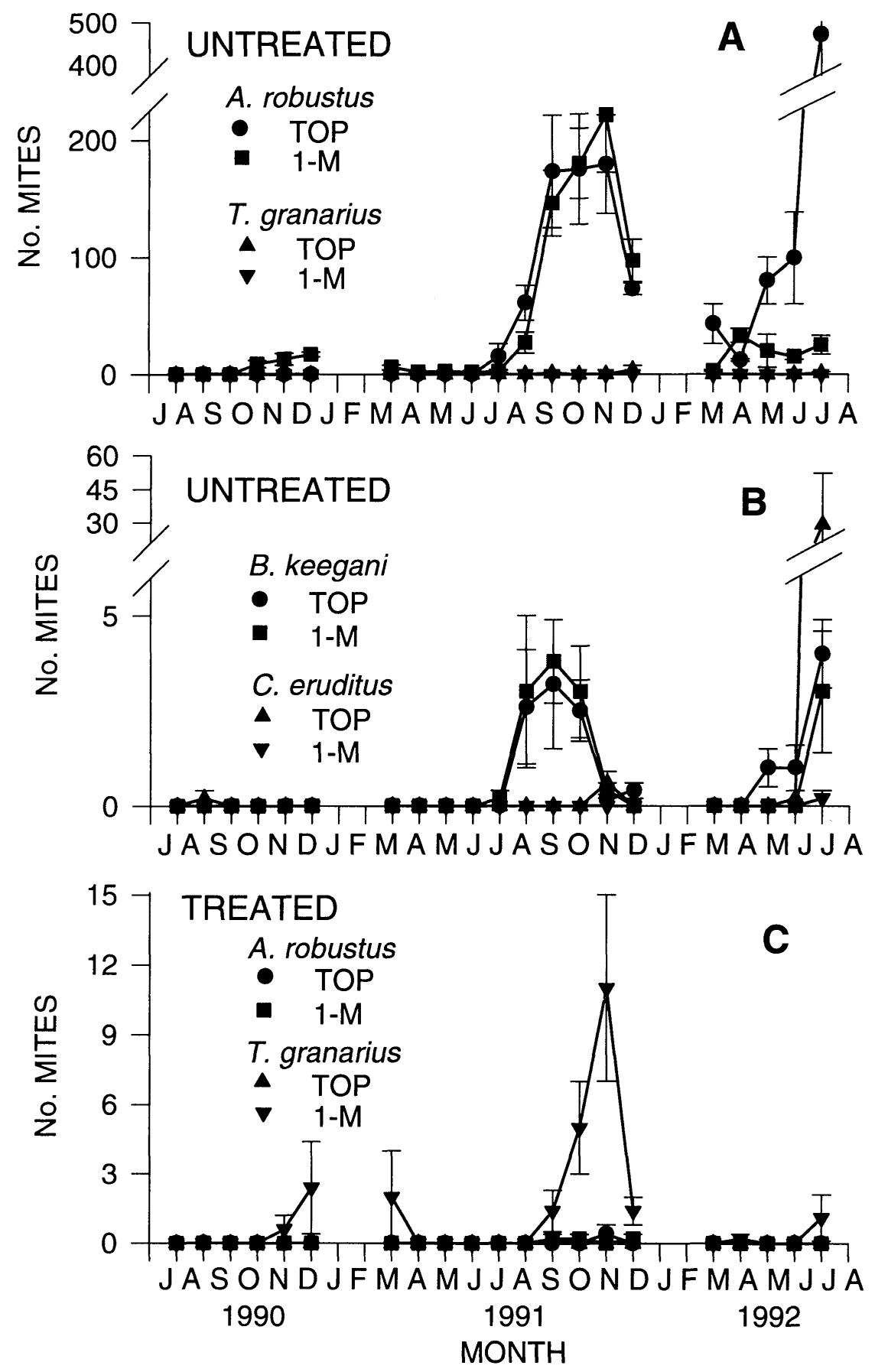

Figure 6. Mean number ( $X \pm S E ; n=5)$ of mites $150 \mathrm{~mL}^{-1}$ of wheat taken monthly, except January and February, over a 24-mo period from the top or 1-m depth of bulks of untreated grain or grain treated with pirimiphos-methyl. 
Table 1. Mean ${ }^{\S}$ seed germination and fungal infection of wheat untreated or treated with pirimiphos-methyl and stored in an unheated granary for 24 mo at Glenlea, Manitoba

\begin{tabular}{|c|c|c|c|c|c|}
\hline & \multirow[b]{2}{*}{$\begin{array}{c}\text { Germination } \\
(\%)\end{array}$} & \multicolumn{4}{|c|}{ Fungal infection } \\
\hline & & $\begin{array}{c}\text { A. glaucus } \\
\text { group } \\
(\%)\end{array}$ & $\begin{array}{c}\text { A. candidus } \\
(\%)\end{array}$ & $\begin{array}{c}\text { Penicillium } \\
(\%)\end{array}$ & $m \mathrm{sp}$. \\
\hline \multicolumn{6}{|c|}{ Sampling after $1 w k$} \\
\hline \multicolumn{6}{|l|}{ Surface } \\
\hline Untreated & $52 \pm 3 a^{\ddagger}$ & $56 \pm 3 a$ & $1 \pm 1 a$ & $37 \pm 9$ & $\mathrm{bc}$ \\
\hline Treated & $61 \pm 2 a$ & $37 \pm 3 b$ & $5 \pm 2 a$ & $42 \pm 1$ & $\mathrm{c}$ \\
\hline \multicolumn{6}{|l|}{ 1-m depth } \\
\hline Untreated & $64 \pm 2 a$ & $28 \pm 2 b c$ & $3 \pm 1 a$ & $28 \pm 3$ & $\mathrm{a}$ \\
\hline Treated & $59 \pm 3 a$ & $22 \pm 3 c$ & $4 \pm 2 a$ & $64 \pm 4$ & $\mathrm{a}$ \\
\hline \multicolumn{6}{|c|}{ Sampling after $24 \mathrm{mo}$} \\
\hline \multicolumn{6}{|l|}{ Surface } \\
\hline Untreated & $13 \pm 1 c$ & $41 \pm 6 \mathrm{~d}$ & $6 \pm 1 \mathrm{bc}$ & $35 \pm 12$ & bcd \\
\hline Treated & $20 \pm 2 b c$ & $37 \pm 3 d$ & $4 \pm 2 a b$ & $20 \pm 2$ & $d$ \\
\hline \multicolumn{6}{|l|}{ 1-m depth } \\
\hline Untreated & $24 \pm 4 b$ & $36 \pm 3 d$ & $12 \pm 6 \mathrm{bc}$ & $15 \pm 3$ & $\mathrm{~d}$ \\
\hline Treated & $13 \pm 4 c$ & $9 \pm 2 \mathrm{e}$ & $12 \pm 4 c$ & $52 \pm 7$ & $b$ \\
\hline
\end{tabular}

Mean $\% \pm \mathrm{SE}, n=10$ replicates of 25 seeds.

$¥$ Means within a column followed by the same letter are not different at the 0.05 level of significance using Duncan's new multiple range test.

\section{Germination and microflora}

Seed germination at $1 \mathrm{wk}$ was the same at all levels in both bins $(P<0.05)$ (Table 1). After 24 mo, all germination had declined sharply and pirimiphos-methyl did not affect germination consistently. Untreated grain from the top of the bulk had lower germination rates than the treated grain. Untreated grain from the $1-m$ depth had higher germination levels than those from the treated bin. The small differences were probably not biologically meaningful.

Aspergillus glaucus group fungi initially infected significantly more seed $(P<0.05)$ on top samples from the untreated wheat than the 1-m depth untreated samples, and both top and 1$m$ depth samples in the treated wheat. By 24 mo, there were no differences in samples from any location except grain from the 1-m depth in the treated bin which had less infection. Aspergillus candidus Link initially had the same low levels of infection on seed from both bins (Table 1). At 24 mo, samples from untreated and treated wheat did not differ by location although 1-m depth samples from the treated bin had higher infection than top samples.

Penicillium spp. infection at the outset was significantly higher in the treated than untreated wheat, particularly at 1-m depth (Table 1). By 24 mo, there was little difference in infection levels in any samples except in wheat from the 1-m depth in the treated bin and from the top of the untreated bin, which had higher levels of infection than other locations.

\section{DISCUSSION}

Insecticide degradation in stored cereals results largely from enzymatic activity in the seeds (Rowlands 1975) or by seed-borne fungi (Anderegg and Madisen 1983) when appropriate temperature and moisture are available (Watters and Mensah 1979). Storage under western Canadian conditions includes cold winter temperatures (Yaciuk et al. 1975) and usually relatively dry grain (Kawamoto et al. 1991). Pirimiphos-rnethyl is quite stable on grain in storage with 
a half-life of $70 \mathrm{wk}$ at $30^{\circ} \mathrm{C}$ and $50 \% \mathrm{RH}$ compared to $12 \mathrm{wk}$ for malathion and 19 wk for chlorpyrifos-methyl [0,0-dimethyl 0-(3,5,6-trichloro-2-pyridyl) phosphorothioate] (Desmarchelier and Bengston 1979). Unlike stored-grain ecosystems treated with malathion (White et al. 1986) or chlorpyrifos-methyl (White and Sinha 1990), the long residual activity of pirimiphos-methyl makes it relatively difficult for most arthropod populations to establish themselves in 24 mo of storage.

No insects other than the psocid $\mathrm{Li}$ poscelis $\mathrm{sp}$. maintained their populations on the untreated wheat throughout the study because of cool grain temperatures. A few Liposcelis sp. survived throughout 24 mo of storage even in wheat treated with pirimiphos-methyl. Psocids feed directly on the germ of grain and can be predators of moth eggs; they are parthenogenetic, have a high reproductive rate and are adapted to both cold and warm climates (Sinha 1988). They also seem to be moderately tolerant to pirimiphos-methyl even at 6 $\mathrm{mg} \mathrm{kg}^{-1}$. Tarsonemus granarius feeds primarily on molds and is often associated with aging stored grain (White and Sinha 1981). This mite survived the winters and reached higher densities in the wheat treated with pirimiphos-methyl than in untreated wheat. Aeroglyphus robustus was first seen in treated grain about 14 mo after storage began and densities remained low compared to the untreated stored-wheat ecosystem. There were also no mite predators in the grain treated with pirimiphos-methyl. Seed germination and microfloral levels changed in 24 mo but did not seem to be related to the insecticide treatment.

In relatively small bulks of grain, cool temperature plays a large role in biological and chemical processes. Nonetheless, the long residual activity of pirimiphos-methyl would prevent communities of insects and mites from becoming established to the same extent as in untreated stored-wheat ecosystems in 24 mo under western Canadian storage conditions. Insecticide treatment can be beneficial because even small populations of pests in un- treated grain pose the threat of exponential increase if grain spoilage or hot spots develop because of moisture entering a granary or migrating from one region of a bulk to another because of air convection currents.

\section{ACKNOWLEDGEMENTS}

We thank R.J. Lamb and I. Wise of the Winnipeg Research Station for critically reviewing this manuscript and $R$. Sims for preparing the figures.

\section{REFERENCES}

Alagusundaram, K., D.S. Jayas, N.D.G. White, and W.E. Muir. 1990. Three-dimensional, finite element, heat transfer model of temperature distribution in grain storage bins. Trans. Am. Soc. Agric. Eng. 33: 577-584.

Anderegg, B.M., and L.J. Madisen. 1983. Degradation of ${ }^{14} \mathrm{C}$-malathion in stored corn and wheat inoculated with Aspergillus glaucus. J. Econ. Entomol. 76: 733736.

ASAE. 1990. Standards, $37^{\text {th }}$ ed. ASAE S352.2 Moisture measurement - grain and seeds. Am. Soc. Agric. Eng., St. Joseph, Michigan.

Desmarchelier, J.M., and M. Bengston. 1979. The residual behaviour of chemicals on stored grain. Pages 138-151 in Proc. $2^{\text {nd }}$ Int. Work. Conf. Stored-Prod. Entomol., Ibadan, Nigeria.

Dunkel, F.V. 1992. The stored grain ecosystem: a global perspective. J. Stored Prod. Res. 28: 73-87.

Fields, P.G. 1992. The control of stored-product insects and mites with extreme temperatures. J. Stored Prod. Res. 28: 89118.

Kawamoto, H., R.N. Sinha, and W.E. Muir. 1991. Regression models for estimation of temperature and moisture content of freshly harvested wheat and barley. Can. Agric. Eng. 33: 321-328.

Mensah, G.W.K., F.L. Watters, and G.R.B. Webster. 1979. Insecticide residues in milled fractions of dry or tough wheat treated with malathion, bromophos, iodofenphos and pirimiphos-methyl. J. Econ. Entomol. 72: 728-731.

Mills, J.T., R.N. Sinha, and H.A.H. Wallace. 1978. Multivariate evaluation of isolation techniques for fungi associated with stored rapeseed. Phytopathology 68: 1520-1525. 
Quinlan, J.K., G.D. White, J.L. Wilson, L.T. Davidson, and L.H. Hendricks. 1979. Effectiveness of chlorpyrifos-methyl and malathion as protectants for high moisture stored wheat. J. Econ. Entomol. 72: 90-93.

Rowlands, D.G. 1975. The metabolism of contact insecticides in stored grains. III. 1970-1974. Residue Rev. 58: 113-155.

Schaafsma, A.W. 1990. Resistance to malathion in populations of Indianmeal moth, Plodia interpunctella (Lepidoptera: Pyralidae). Proc. Entomol. Soc. Ont. 121: 101-104.

Sinha, R.N. 1964. Mites of stored grain in western Canada. Ecology and survey. Proc. Entomol. Soc. Manit. 20: 19-33.

Sinha, R.N. 1966. Aeroglyphus robustus, a pest of stored grain. J. Econ. Entomol. 59: 686-688.

Sinha, R.N. 1988. Population dynamics of Psocoptera in farm-stored grain and oilseed. Can. J. Zool. 6: 2618-2627.

Snelson, J.T. 1987. Grain protectants. AClAR Monograph No. 3, Canberra, Australia, $448 \mathrm{p}$.

Wallace, H.A.H., and R.N. Sinha. 1962. Fungi associated with hot spots in farm stored grain. Can. J. Plant Sci. 42: 130-141.

Watters, F.L., and G.W.K. Mensah. 1979. Stability of malathion applied on stored wheat for control of rusty grain beetles. J. Econ. Entomol. 72: 794-797.
White, N.D.G., and J.G. Leesch. 1995. Chemical control. In B. Subramanyam and D.W. Hagstrum (eds.), Management of insects in stored products. Marcel Dekker Inc., New York (in press).

White, N.D.G., and S.R. Loschiavo. 1985. Testing for malathion resistance in fieldcollected populations of Cryptolestes ferrugineus (Stephens) and factors affecting reliability of the tests. J. Econ. Entomol. 78: 511-515.

White, N.D.G., and R.N. Sinha. 1981. Life history and population dynamics of the mycophagous mite Tarsonemus granarius Lindquist (Acarina: Tarsonemidae). Acarologia 22: 353-360.

White, N.D.G., and R.N. Sinha. 1990. Effect of chlorpyrifos-methyl on oat ecosystems in farm granaries. J. Econ. Entomol. 83: 1128-1134.

White, N.D.G., R.N. Sinha, and J.T. Mills. 1983. Malathion applied to wheat as it enters a granary. Canadex 705.67. Communications Branch, Agriculture Canada, Ottawa, Ont.

White, N.D.G., R.N. Sinha, and J.T. Mills. 1986. Long-term effects of an insecticide on a stored-wheat ecosystem. Can. J. Zool. 64: 2558-2569.

Yaciuk, G., W.E. Muir, and R.N. Sinha. 1975. A simulation model of temperatures in stored grain. J. Agric. Eng. Res. 20: 245258. 